\title{
Reproduction Performance and Management of Dairy Cattle
}

\author{
Scott MCDOUGALL1) \\ 1)Animal Health Centre, PO Box 21, Morrinsville, New Zealand
}

\begin{abstract}
Internationally, reproductive performance of dairy cattle is declining. Under the low production, pasture-based and seasonal calving system used in New Zealand, reproductive performance is also declining, but remains higher than for many other industries. The seasonal calving system requires a high level of reproductive performance to ensure a 365 day inter-calving interval. About $80 \%$ of cows are detected in oestrus and inseminated in the first 3 weeks of the seasonal breeding programme and have a conception rate of $55 \%$ to $65 \%$ to this first insemination. This results in $\sim 75 \%$ and $\sim 90 \%$ of cows being pregnant by 6 weeks and by the end of the breeding programme, respectively. However, reproductive performance is declining due to multiple factors including increasing herd size, reduced oestrus detection sensitivity and specificity, declining body condition score at calving and increased rate of body condition score loss postpartum. Continuing selection for increased milk production is also having negative effects on reproduction. The mechanisms by which high production and negative energy balance are reducing reproductive performance are becoming better understood. However, practical solutions for the problem are challenging for veterinarians and consultants, especially given the consumer preference for less interventions.
\end{abstract}

Key words: Dairy cattle, Reproduction, Pasture

(J. Reprod. Dev. 52: 185-194, 2006)

R eproductive performance of dairy cows is declining both in pasture-based [1] and more intensive production systems [2-4]. However, reproductive performance varies among production systems with the pasture based systems of Australia and New Zealand having better performance than reported from the USA and Europe. Under predominantly pasture-based systems in Australia and New Zealand, 80\% of cows are detected in oestrus and inseminated ('submission rate') within 3 weeks of commencement of the seasonal breeding programme, $53-55 \%$ of cows conceive to first insemination, $68-75 \%$ of cows are pregnant by 6 weeks after the start of the breeding programme and $90-94 \%$ are pregnant by the end of the seasonal breeding programme $[5,6]$. Similarly in pasture based systems in Ireland, an Irish study found submission rates by 3 weeks, conception to first

Correspondence: S. McDougall (e-mail: smcdoug@ahc.co.nz) service and pregnancy rate by 6 weeks after the start of breeding to be $81 \%, 49 \%$ and $57 \%$, respectively [7]. In contrast, U.K. studies have found the conception rate to first service to be only $30 \%$ to $40 \%[3,8]$ and the proportion of eligible cows detected in oestrus in 3 weeks is only $30-50 \%$ [8], resulting in low proportion of cows conceiving each 21 days. Conception rate to service has declined from $65 \%$ to $40 \%$ as production has increased from 4500 to $9000 \mathrm{~L} /$ cow / lactation between 1951 to 1996 in the USA [2]. The average days open increased from 124 to 168 days and services per conception from 1.85 to 3.0 from 1976 to 1999 in Friesian herds in southern USA during which time cow production and herd size increased [9].

The declining performance and the differences among systems are likely to be due to changes and differences in both management and cow genetics. 


\section{Dairy Production Systems}

\section{New Zealand seasonal calving}

The New Zealand dairy production system is characterised as a generally low nutritional input system with limited use of total mixed rations and of cereal grains [10]. The milk yield is generally lower than industries in which total mixed rations are used (e.g. total lactation production was $3791 \mathrm{~L}$ or $322 \mathrm{~kg}$ milk fat and protein/cow/year in 200304; www.lic.co.nz). The seasonal calving and breeding system used in New Zealand is driven by the seasonal variation in pasture productivity and quality [11], resulting in an absolute requirement for a 365 day inter-calving interval. Seasonal calving results in efficient and effective use of labour and other resources due to a seasonal focus on management tasks such as calving, oestrous detection and breeding programmes. Seasonal breeding programmes also result in a high probability that sexually active groups of at least 3 cows will form, thus enhancing the probability accuracy of detection of oestrus [12]. However, failure of a cow to conceive within the 12-14 week breeding season results in either culling or the cost of carrying non-pregnant animals through to the next breeding period. The economics of the system are dependent on the subsequent calving pattern (which has impacts on the subsequent breeding programme and on gross milk production over the finite lactational season) and the proportion of involuntary (i.e. non-pregnant) culls. The major reproductive challenge within the New Zealand system is that of extended postpartum anoestrus, with about $20 \%$ of cows not having been detected in oestrus by the commencement of the seasonal breeding programme [13]. Such cows are less likely to be inseminated, to conceive and hence survive to the next lactation. The majority of cows examined as 'not detected in oestrus' do not have a palpable corpus luteum, indicating that failure of ovulation, rather than failure of oestrus detection, is the major problem. Risk factors for anoestrus which have been identified have included age (young >old), interval from calving to start of the seasonal breeding programme (short $>$ long), peri-partum disease, an extended period of negative energy balance, breed (Friesian $>$ Jersey) and body condition score at calving (low $>$ high). Reproductive management is focused on ensuring optimal calving patterns including use of induction of parturition [14] and treatment of those cows 'not detected in oestrus' before the commencement of the seasonal breeding programme [13]. Peripartum disease prevalence is also lower than reported internationally [15], although recent studies have shown biological and economic advantages in identifying and treating these animals [16].

\section{Year-round calving}

In the year-round calving systems practiced in many dairy industries, the reproductive problems appear somewhat different. Expression and detection of oestrous, with low conception rates, appear to be major problems. The proportion of eligible cows detected in oestrus in 3 weeks is only $30-50 \%$ [8]. This may be a combination of factors including anoestrus, failure to express oestrous with ovulation, management failure to detect oestrous, small sexually active groups, use of tie stall barns, poor design of footing such that there is an increased risk of cows slipping when mounting etc. Additionally, the conception rate to service appears to be only $30-40 \%$ [8], due to false positive oestrus detection, thus insemination at the incorrect stage of the cycle, cows being inseminated when in negative energy balance (e.g. declining body condition, [17]), cows having poor genotypic fertility, heat stress and/or high incidence of embryonic or foetal mortality [18]. The net effect of both low submission and low conception rate is a low pregnancy rate. It has been estimated that if the average year-round calving herd with a voluntary wait period of 65 days, a heat detection rate of $48 \%$ and a conception rate of $44 \%$ were to improve performance to achieve a voluntary wait period of 50 days, a $65 \%$ heat detection rate and $50 \%$ conception rate then the net benefit would be $£ 183 /$ cow /year [8].

Herd reproduction performance is dependent on cow, nutritional, management and genetics factors. The observed differences in reproductive performance among the dairy systems are due to multiple factors including the production system (e.g. indoors vs. outdoors, seasonal vs. year round breeding, total mixed ration vs. predominantly pasture based nutrition) as well as cow genetics. Nutritional and production differences among systems likely interact to influence reproductive performance and to explain observed differences in reproductive performance. Year-round calving 
systems often use higher levels of external feed inputs and hence achieve higher levels of milk production than the pasture-based systems. For example, current average USA milk production is > $9000 \mathrm{~L} / \mathrm{cow} /$ lactation in comparison to the New Zealand average production of $3791 \mathrm{~L} / \mathrm{cow} /$ lactation. Dairy production systems vary internationally due to differences in physical environment, the relative cost of labour, nutrition economics, breeding costs, milk yield monitoring costs, the availability of infrastructure, and the regulatory environment. Introduction of production quotas also alters the economics and management systems [19]. These systems differences will affect reproductive performance and the cost effectiveness of reproductive interventions and technologies.

\section{Mechanisms for Interaction of Nutrition, Genotype and Reproduction}

Cows undergo a period of negative energy balance post partum as nutrient requirements for milk production exceed nutrient intake $[20,21]$. To meet demands of production, lipid mobilisation is increased in late gestation and early lactation [22], controlled by changes in insulin sensitivity [23]. Post partum resumption of cycling activity occurs after the nadir of negative energy balance [24]. Body condition score (BCS), a proxy for energy balance, has been shown to be associated with a number of reproductive outcomes. Low BCS at calving is associated with extended post partum anoestrous intervals [25], lower submission rates [7], lower first service conception rates [5,7] and lower 6-week pregnancy rates [5]. Conception rates decline with excessive losses of BCS post partum both in pasture based systems [5] and more intensive management systems [17, 26, 27]. Where BCS was assessed on the day of AI, cows in low condition score (i.e. $<3)$ and in higher $\mathrm{BCS}(>3 ; 1$ to 5 scale) had lower chance of conceiving than cows at $\mathrm{BCS}=3$ [17]. Positive genetic relationships between BCS and fertility have been demonstrated, suggesting that selection for higher BCS would likely results in better reproductive performance $[28,29]$. Body condition score may be closely associated with reproduction as accumulation of body reserves prepartum to meet the demands of post partum lactation may be an important selection advantage for mammals. Recently, it has been proposed that there may be genetically determined changes in optimal body lipid reserves at different stages of gestation, hence there may be a genetically determined optimal loss of body lipid post partum. It is also proposed that these coordinated changes in metabolism (i.e. homeorhesis) are 'defended' such that deviations from the optimal body lipid post partum (e.g. due to under and overfeeding) result in changes in metabolism to ensure that optimal lipid reserves are re-established [30].

Relationships between milk yield or milk composition and reproductive performance are less clear. In one New Zealand study, milk production, milk fat yield and milk protein yield were inversely related to the calving to conception interval [31]. Under Irish management systems, milk protein yield and protein to fat ratio were positively correlated with 3 week submission rate, 305-day milk yield was positively correlated with probability of conception to first service and yield around the time of first service was positively associated with 6 week pregnancy rate [7]. However, many studies have found negative phenotypic associations between milk production and reproductive performance [3, 32]. Genetic selection for increased milk production has resulted in cows with markedly improved potential for milk production. Use of these genotypes has been associated with a phenotypic decline in conception rates and other measures of reproduction performance. These cows have lower average lactation BCS and lose more body condition in early lactation [33, 34]. Additionally, negative genotypic associations between milk production and reproductive performance have been demonstrated both in pasture-based production systems [35] and more intensive production systems [36]. Recent studies in New Zealand (Pryce pers com) and the US [37] have not found genotype by nutritional environment interactions for reproductive performance. This suggests that the current cow genotypes will have the same reproductive performance over a range of nutritional systems. However, further work is required in this area.

The paradox of increased production being associated with better reproductive performance in pasture based systems may be due to differences in absolute levels of production in the New Zealand 
and Irish studies and those in USA and Europe. That is, if the relationship between production and reproduction were curvilinear, those industries at a relative low level of production may see positive relationship between production and reproduction, while at higher levels the relationship may be reversed. Alternatively the production system itself may influence the relationship between production and reproduction as in the pasture based systems cows are competing for a scarce feed resource, so that cows that forage competitively have higher feed intakes and hence higher production as well as being less likely to be in negative energy balance than herd mates that do not compete as well. A recent Dutch data demonstrates that the antagonistic relationships between production and reproduction may be modified by the intensity of the management systems and that analysis at herd level may give different interpretations of analysis compared with within herd analysis. On average, high producing herds had shorter intervals from calving to first service than lower producing herds. However, within a high production herd, individual high producing cows had longer intervals from calving to first service in high production herds [38]. Thus, overall farm management may improve average performance of the average cow within a herd, but individuals within that herd may have reduced performance as the physiological limits of production and reproduction are met. Conversely, the herd and individual cows in poorly managed and low production herds may have poor reproductive performance, but for reasons unrelated to the antagonistic relationship between production and reproduction. The practical implication of this is that genotype of cow may be limiting reproductive performance in some herds but not others and that detailed analysis of the farm systems, genetics and reproductive performance is required before systems or cow genetics are changed.

The physiological relationships between production, nutrition and reproduction are complex and multi-factorial.

The negative reproductive effects of postpartum negative energy balance and/or undernutrition are mediated via the hypothalamic/pituitary axis, the GH-IGF axis and/or via direct effects on follicular function $[46,47]$. Undernutrition leads to reduced
GnRH and LH pulse frequency mediated by increased sensitivity to oestradiol feedback. This results in a slower rate of follicle growth, smaller maximum follicle size and reduced oestradiol production. However, effects of undernutrition independent to changes in gonadotrophins demonstrate that other mechanisms are operating. Depressed insulin-like growth factor 1 (IGF-1), insulin and glucose concentrations and increased growth hormone concentrations are observed postpartum. Intrafollicular IGF-1, of both local and systemic origin, interacts with gonadotrophins to control follicle growth, cell differentiation and steroid production. The effects of IGF within the follicle are also mediated by binding proteins and proteases [48]. Cows selected for high milk yield have high GH and low IGF and insulin concentrations [49]. Additionally, differences in GH and IGF concentrations between HolsteinFriesian genotypes have been observed and may contribute to the observed differences in reproductive performance among the genotypes. Concentrations of non esterified fatty acids are elevated during periods of post partum negative energy balance due to body lipid mobilisation. Negative effects of non esterified fatty acids on granulosa cell proliferation as well as reduced rate of meiosis, lower fertilisation rates and slower cleavage and blastocyst development have been demonstrated in vitro [50] illustrating direct effects of metabolites on ovarian function.

Higher milk production has been associated with higher concentrations of FSH and LH preovulation and higher rates of multiple ovulations [39]. This may be associated with higher levels of feed intake in higher producing animals, which in turn is associated with increased liver blood flow and an increased rate of metabolic clearance of oestradiol and progesterone [41] and reduction in intensity of negative feed-back loops. Cows selected for high milk production have lower luteal phase blood progesterone than those not selected for production [4] and the incidence of abnormal oestrus cycles also appears to be increasing [44, 45].

The duration of oestrus is reduced in higher producing cows [40] and cows mobilising more body tissue, losing more weight and hence being in negative energy balance are less likely to express oestrus [17, 42, 43]. 


\section{Practical Approaches to Improving Dairy Cattle Reproductive Performance at Herd Level}

Recent research has improved the understanding of the mechanisms by which high production and/ or negative energy balance has resulted in a decline in reproductive performance. However, at a practical level, maintaining reproductive performance is challenging for veterinarians, nutritionists and herd managers. Given the multifactorial nature of risk factors for reproduction at herd level, reductionist research may not provide solutions. However, use of a production medicine approach which logically examines the whole farm system to identify risk factors has been used with some success [51].

Optimising reproduction performance at herd level requires measurement of current performance, assessment of areas in which performance is less than desirable against agreed targets, and appropriate interventions. Performance needs to be assessed not only on an individual cow basis, but also at herd and general management level. For example, focusing on individual cow treatments when the major factor limiting reproduction performance is poor nutrition or poor oestrous detection, will not result in improvement in overall farm performance.

An approach to improving herd reproductive performance can be summarised as:

- Define the problem

- Collect a detailed history (e.g. review the reproduction data such as calving pattern, submission rates, conception rates, pregnancy rates, cull rates) and undertake an analysis of data stratified by common risk factors such as age, breed, calving pattern, peri partum disease etc.

- Collect additional data or perform tests as required e.g.

- Assess nutrition status via farm walks, feed budgeting, pasture quality assessment, trace elements status, milk production and milk composition

- Assess farm reproductive management e.g. semen handling and AI technique, oestrus detection systems and efficiency, sire selection policy

- Define disease status e.g. prevalence of endometritis, retained foetal membranes, dystocia, mastitis, lameness, prevalence of corpus luteum positive negative cows among cows not detected in oestrus, presence of BVD, neospora etc.

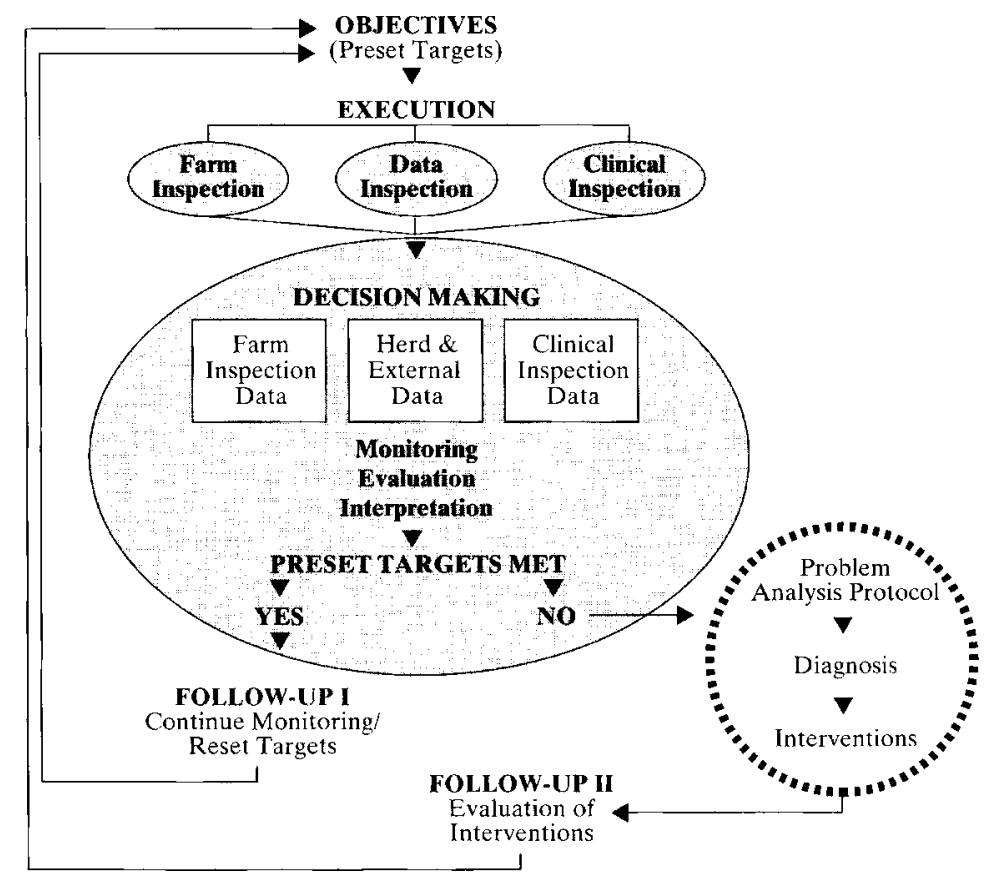

Fig. 1. A scheme for systematic approach to reproduction problem solving [51]. 
Assess level or embryo/fetal loss

- Identify key risk factors for suboptimal reproductive performance (reach a diagnosis)

- Implement appropriate treatments and/or management changes

- Monitor the outcome and check that targets are being met (Fig. 1)

\section{Obtaining the history}

Often key reproduction data is missing when a herd is initially assessed e.g. recording of peripartum diseases is often poor; and as pregnancy testing may be missing estimates of embryo loss rate data is difficult. Often, establishment of better data collection systems is one of the first steps in trying to improve performance of a herd. However, examination of simple records such as the calving date data, age structure of the herd, peripartum disease records, data from breeding records, pregnancy data or subsequent calving data can be undertaken and some level of understanding of the problem developed. A structured history taking session with the herdowner assessing farm nutritional, culling and breeding policy is invaluable to understand the herdowners objectives and concerns as well as providing some clues as to possible aetiology of the problems.

\section{Data sources include:}

- Herdowner records

- Hard copy recording sheets and books of disease occurrence, breeding dates, nutritional management etc.

- Veterinary records

- Dates and numbers of individual cow treatments for peripartum disease and noncycler treatments

- Use of reproductive vaccines etc.

- National dairy database

- Electronic downloads of calving data, breed, age, AI dates, milk production records

- Farm consultant reports

- Farm level nutritional management including pasture quality and quantity, fertiliser records etc.

- Cow body condition score records

- Estimated pasture and other feed intakes etc.

- Heifer grazier records

- Mating dates

- BCS and weights
Trace element records

- Herd level milk production data

- Processor records via electronic and hardcopy formats

What are reasonable targets?

No nationally agreed reproductive targets exist in New Zealand. However, targets have been developed from the results of trial work (where early pregnancy testing and detailed data analysis of records has been undertaken) as well as analysis of whole pregnancy test data from commercial herds [52] to develop targets. The targets are the median of top $25 \%$ of herds performance (Table 1 ; Fig. 2 a,b).

What interventions are available?

- Nutritional and body condition score management

- Shortening of lactation to ensure adequate time is available to reach optimal calving body condition score

- Strategic and long term increases in pasture and supplementary feed inputs

- Assessment and correction of trace element deficiencies

- Calving spread manipulation

- Shortening the length of breeding programme

- Induction of parturition

- Selective culling of cows conceiving late in the seasonal breeding programme

- Improving submission, conception and pregnancy rates

- Concentrated calving patterns

- Early evaluation and treatment of endometritis and pyometron

- Early evaluation and treatment of noncycling cows

- Maintenance of pasture intake and quality throughout breeding programme

- Minimising pregnancy loss by minimising disease risk

- Disease monitoring

- Reproductive vaccine usage (e.g. BVDV, neospora, leptospirosis)

- Biosecurity e.g. bull and cow quarantine procedures

Various interventions to improve individual cow reproductive performance have been evaluated with controlled randomised intervention studies 

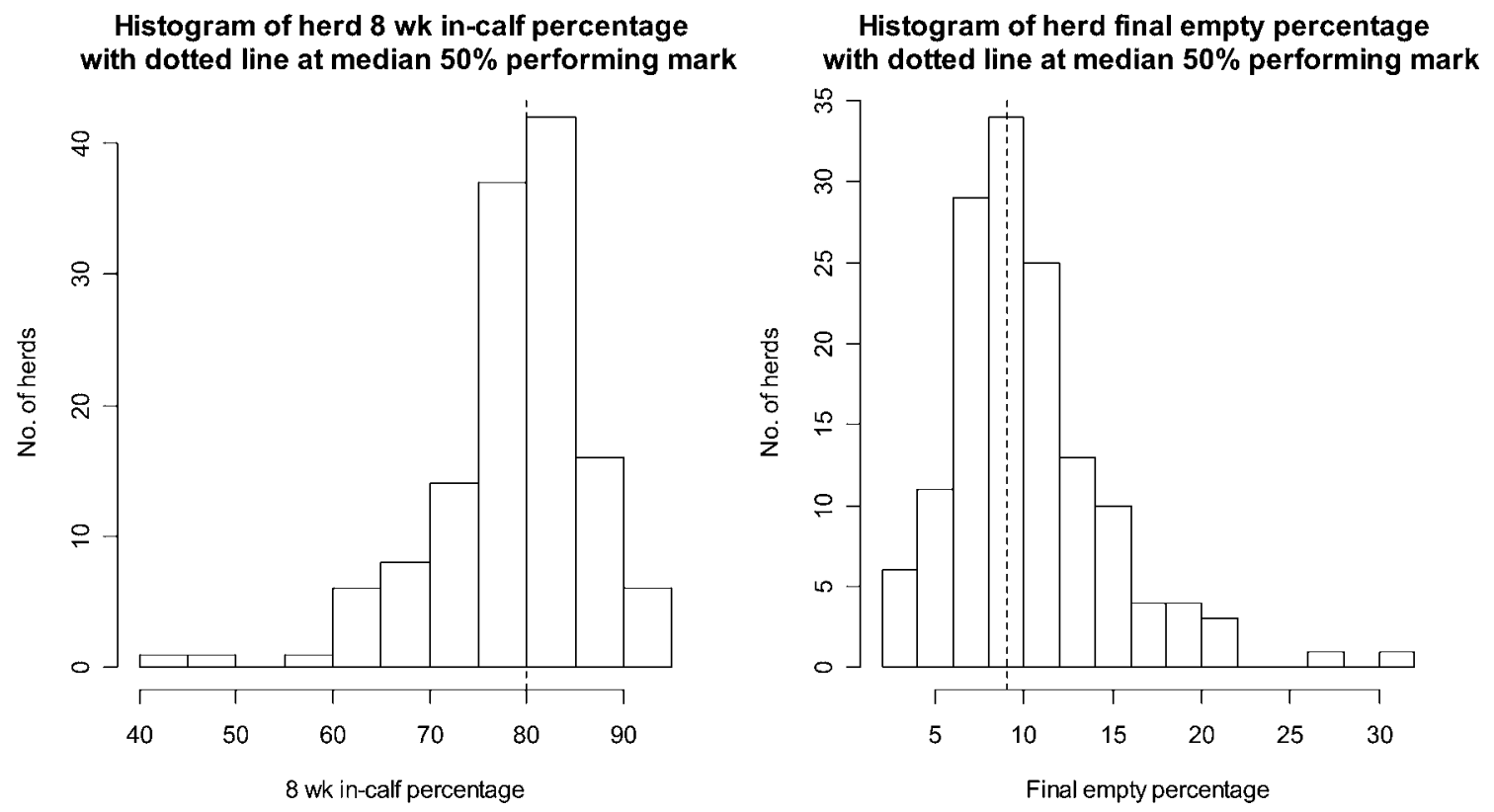

Fig. 2. Frequency distribution of 8-week and final pregnancy rates for $125 \mathrm{New}$ Zealand dairy herds [52].

Table 1. Suggested targets for reproductive performance of seasonally calving dairy herds

\begin{tabular}{lc}
\hline Measure & Target \\
\hline Cows not calved by 4 weeks before start of breeding programme (\%) & 0 \\
Cows failing to calve after confirmed pregnancy diagnosis (\%) & $<6$ \\
Days to half cows calved & 18 \\
Days to three quarters cows calved & 30 \\
Days to all cows calved & 56 \\
Cows not detected in oestrus before start of breeding (\%) & $<20$ \\
3-week submission rate (\%) & $>80$ \\
3-week pregnancy rate (\%) & $>47$ \\
6-week pregnancy rate (\%) & $>68$ \\
8-week pregnancy rate (\%) & $>85$ \\
Total length of mating period (days) & $<85$ \\
Not pregnant at end of breeding programme (\%) & $<6$ \\
\hline
\end{tabular}

including diagnosis and treatment of peripartum disease [16], and treatment of cows not detected in oestrous by the start of the seasonal breeding programme [53]. However, other interventions such as reducing milking frequency to once daily for cows not cycling [54], supplementing cows with energy sources such as mono propylene glycol [55], or placement of vasectomised bulls with the herd remain either untested or unproven under New Zealand management systems. Further research is required, especially at herd and farm systems level to define general, nutritional and breeding management factors associated with good reproductive performance and to define the biological and economic benefit of various hormonal and non-hormonal interventions in dairy farm systems.

\section{Conclusions}

The reproductive performance of the New Zealand dairy cows appears to be relatively good and to have declined less than for some other dairy industries. Factors that may be enhancing performance include the managerial advantages of 
seasonality of calving and breeding, the relatively low nutritional input pasture-based production system which results in relatively low production and the focus on reproductive management by herdowners, veterinarians, advisors and geneticists to maintain a 365-day inter-calving interval. Although some hormonal interventions are used in the New Zealand dairy industry, usage is declining, and the research, extension, veterinary and herdowner focus is on improved nutrition and management systems to prevent reproductive problems, rather than increasing reliance on hormonal treatments. However, there is continued pressure on the economics of production, resulting in larger farms and a continued drive for increasing production, with likely negative effects on reproductive performance. Thus, there is an ongoing requirement to improve management and nutrition as well as to ensure that fertility is adequately represented within the industries industry's breeding objectives.

Internationally, selection for milk production has resulted in perturbation of the reproductive and metabolic axes resulting in reduced fertility. Changes to nutritional and breeding management systems will be required to reduce the effect of these perturbations, if reproductive performance is to be maintained in these high producing animals.

\section{References}

1. Harris BL. Multiple trait fertility model for national genetic evaluation. 2005; www.aeu.org.nz.

2. Butler WR. Review: Effect of protein nutrition on ovarian and uterine physiology in dairy cattle. $J$ Dairy Sci 1998; 81: 2533-2539.

3. Royal MD, Darwash AO, Flint APF, Webb R, Woolliams JA, Lamming GE. Declining fertility in dairy cattle: Changes in traditional and endocrine parameters of fertility. Anim Sci 2000; 70: 487-501.

4. Lucy MC. Reproductive loss in high-producing dairy cattle: where will it end? J Dairy Sci 2001; 84: 1277-1293.

5. Morton J. The In-Calf project - Identifying risk factors for reproductive performance in Australian dairy herds. Cattle Practice 2003; 11: 201-208.

6. Xu ZZ, Burton L. Reproductive performance of dairy cows in New Zealand. 2004; www.aeu.co.nz.

7. Buckley F, O'Sullivan K, Mee JF, Evans RD, Dillon P. Relationships among milk yield, body condition, cow weight, and reproduction in spring-calved Holstein-Friesians. J Dairy Sci 2003; 86: 2308-2319.

8. Esslemont RJ. The costs of poor fertility and what to do about reducing them. Cattle Practice 2003; 11: 237-250.

9. Washburn SP, Silvia WJ, Brown $\mathrm{CH}, \mathrm{McDaniel}$ BT, McAllister AJ. Trends in reproductive performance in south-eastern Holstein and Jersey DHI herds. J Dairy Sci 2002; 85: 244-251.

10. Verkerk G. Pasture-based dairying: challenges and rewards for New Zealand producers. Theriogenology 2003; 59: 553-561.

11. Holmes CW, Brookes IM, Garrick DJ, MacKenzie DDS, Parkinson TJ, Wilson GF. Milk Production from Pasture. Palmerston North, New Zealand; Massey University: 2002.

12. Kilgour R, Skarsholt BH, Smith JF, Bremner KJ, Morrison MCL. Observations on the behaviour and factors influencing the sexually-active group in cattle. Proceedings of the New Zealand Society of Animal Production; 1977; 37: 128-135.

13. Rhodes FM, McDougall S, Burke CR, Verkerk GA, Macmillan KL. Treatment of cows with an extended postpartum anestrous interval. J Dairy Sci 2003; 86: 1876-1894.

14. MacDiarmid SC. Betamethasone for the induction of parturition in dairy cows: A comparison of formulations. N Z Vet J 1980; 28: 61-64.

15. McDougall S. Effect of periparturient disease on the reproductive performance of New Zealand dairy cows. N Z Vet J 2001; 49: 60-67.

16. McDougall S. Effect of intrauterine antibiotic treatment on reproductive performance of dairy cows following periparturient disease. $N$ Z Vet J 2001; 49: 150-158.

17. Loeffler $\mathbf{S H}$, deVries $\mathbf{M J}$, Schukken $\mathbf{Y H}$, deZeeuw AC, Dijkhuizen AA, deGraaf FM, Brand A. Use of AI technician scores for body condition, uterine tone and uterine discharge in a model with disease and milk production parameters to predict pregnancy risk at first AI in Holstein dairy cows. Theriogenology 1999; 51: 1267-1284.

18. Santos JEP, Thatcher WW, Chebel RC, Cerri RLA, Galvao KN. The effect of embryonic death rates in cattle on the efficacy of estrus synchronization programs. Anim Reprod Sci 2004; 82-83: 513-535.

19. van Arendonk JAM, Liinamo A-E. Dairy cattle production in Europe. Theriogenology 2003; 59: 563569.

20. Bauman DE, Currie WB. Partitioning of nutrients during pregnancy and lactation: A review of mechanisms involving homeostasis and homeorhesis. J Dairy Sci 1980; 63: 1514-1529.

21. Butler WR, Everett RW, Coppock CE. The relationships between energy balance, milk 
production and ovulation in postpartum Holstein cows. J Anim Sci 1981; 53: 742-748.

22. Chilliard Y, Ferlay A, Faulconnier Y, Bonnet M, Rouel J, Bocquier F. Adipose tissue metabolism and its role in adaptations to undernutrition in ruminants. Proc Nutr Soc 2000; 59: 127-134.

23. Vernon RG, Denis RGP, Sorensen A. Signals of adiposity. Dom Anim Endocrinol 2001; 21: 197-214.

24. Canfield RW, Butler WR. Energy balance, first ovulation and the effects of naloxone on $\mathrm{LH}$ secretion in early postpartum dairy cows. J Anim Sci 1991; 69: 740-746.

25. Grainger C, Wilhelms G. Effect of duration and pattern of underfeeding in early lactation on milk production and reproduction of dairy cows. Aust $J$ Exp Agric Anim Husb 1979; 19: 395-401.

26. Butler WR, Smith RD. Interrelationships between energy balance and postpartum reproductive function in dairy cattle. J Dairy Sci 1989; 72: 767-783.

27. Domecq JJ, Skidmore AL, Lloyd JW, Kaneene JB. Relationship between body condition score and conception to first artificial insemination in a large dairy herd of high yielding Holstein cows. J Dairy Sci 1997; 80: 113-120.

28. Berry DP, Buckley F, Dillon P, Evans RD, Rath M, Veerkamp RF. Genetic relationships among body condition score, body weight, milk yield, and fertility in dairy cows. J Dairy Sci 2003; 86: 21932204.

29. Harris BL, Pryce JE. Genotypic and phenotypic relationships between milk protein percentage, reproductive performance and body condition score in New Zealand dairy cattle. Proceedings of the New Zealand Society of Animal Production; 2004; 64: 127-131.

30. Friggens NC, Ingvartsen KL, Emmans GC. Prediction of body lipid change in pregnancy and lactation. J Dairy Sci 2004; 87: 988-1000.

31. McDougall S, Clark DA, Macmillan KL, Williamson NB. Some effects of feeding pasture silage as a supplement to pasture on reproductive performance in lactating dairy cows. N Z Vet J 1995; 43: 4-9.

32. Hoekstra J, van der Lugt AW, van der Werf JHJ, Ouweltjes W. Genetic and phenotypic parameters for milk production and fertility traits in upgraded dairy cattle. Livest Prod Sci 1994; 40: 225-232.

33. Grainger C, Davey AWF, Holmes CW. Performance of Friesian cows with high and low breeding indexes. 1. Stall feeding and grazing experiments and performance during the whole lactation. Anim Prod 1985; 40: 379-388.

34. Veerkamp RF, Simm G, Oldham JD. Effects of interaction between genotype and feeding system on milk production, feed intake, efficiency and body tissue mobilization in dairy cows. Livest Prod Sci 1994; 39: 229-241.
35. Grosshans T, Xu ZZ, Burton LJ, Johnson DL, Macmillan KL. Performance and genetic parameters for fertility of seasonal dairy cows in New Zealand. Livest Prod Sci 1997; 51: 41-51.

36. Pryce JE, Veerkamp RF. The incorporation of fertility indices in genetic improvement programmes. In: Fertility in the High Producing Dairy Cow; Publication 26. British Society of Animal Science; 2001: 237-249.

37. Kearney JF, Schutz MM, Boettcher PJ. Genotype x environment interaction for grazing vs. confinement. II. Health and reproduction traits. $J$ Dairy Sci 2004; 87: 510-516.

38. Windig JJ, Calus MPL, Veerkamp RF. Influence of herd environment on health and fertility and their relationship with milk production. J Dairy Sci 2005; 88: 335-347.

39. Lopez H, Caraviello DZ, Satter LD, Fricke PM, Wiltbank MC. Relationship between level of milk production and multiple ovulations in lactating dairy cows. J Dairy Sci 2005; 88: 2783-2793.

40. Lopez H, Satter LD, Wiltbank MC. Relationship between level of milk production and estrous behavior of lactating dairy cows. Anim Reprod Sci 2004; 81: 209-223.

41. Sangsritavong S, Combs DK, Sartori R, Armentano LE, Wiltbank MC. High feed intake increases liver blood flow and metabolism of progesterone and estradiol-17 $\beta$ in dairy cattle. $J$ Dairy Sci 2002; 85: 2831-2842.

42. Heuer C, Schukken YH, Dobbelaar P. Postpartum body condition score and results from the first test day milk as predictors of disease, fertility, yield, and culling in commercial dairy herds. J Dairy Sci 1999; 82: 295-304.

43. Westwood CT, Lean IJ, Garvin JK. Factors influencing fertility of Holstein cows: A multivariate description. J Dairy Sci 2002; 85: 3225-3237.

44. Opsomer G, Coryn M, Deluyker H, Kruif AD. An analysis of ovarian dysfunction in high yielding dairy cows after calving based on progesterone profiles. Reprod Dom Anim 1998; 33: 193-204.

45. Lamming GE, Darwash AO. The use of milk progesterone profiles to characterise components of subfertility in milked dairy cows. Anim Reprod Sci 1998; 52: 175-190.

46. Diskin MG, Mackey DR, Roche JF, Sreenan JM. Effects of nutrition and metabolic status on circulating hormones and ovarian follicle development in cattle. Anim Reprod Sci 2003; 78: 345370 .

47. Hunter MG, Robinson RS, Mann GE, Webb R. Endocrine and paracrine control of follicular development and ovulation rate in farm species. Anim Reprod Sci 2004; 82-83: 461-477.

48. Lucy MC. Regulation of ovarian follicular growth by somatotropin and insulin-like growth factors in 
cattle. J Dairy Sci 2000; 83: 1635-1647.

49. Richards MW, Wettemann RP, Spicer LJ, Morgan GL. Nutritional anestrus in beef cows: Effects of body condition and ovariectomy on serum luteinizing hormone and insulin-like growth factorI. Biol Reprod 1991; 44: 961-966.

50. Jorritsma R, Cesar ML, Hermans JT, Kruitwagen CLJJ, Vos PLAM, Kruip TAM. Effects of nonesterified fatty acids on bovine granulosa cells and developmental potential of oocytes in vitro. Anim Reprod Sci 2004; 81: 225-235.

51. Brand A, Guard CL. Principles of herd health and production management programmes. In: Brand A, Noordhuizen JPTM, Schukken YH (eds.), Herd Health and Production Management in Dairy Practice. Wageningen: Wageningen Pers; 1996: 3-14.

52. Compton C, McDougall S. Survey of bulk tank milk
BVDV antibody tests and reproductive performance in 141 Waikato dairy herds. In: BVDV Symposium; 2005; Wellington, New Zealand. 241: 87-95.

53. McDougall S, Compton C. Reproductive performance of anestrous dairy cows treated with progesterone and estradiol benzoate. J Dairy Sci 2005; 88: 2388-2400.

54. Rhodes FM, Clark BA, Macmillan KL, McDougall S. Use of once a day milking or treatment with progesterone and oestradiol benzoate in anoestrous cows. Proc N Z Soc Anim Prod 1998; 58: 44-46.

55. Tunon GE, Taufa VK, Burke CR, Holmes CW, Chagas LM. Efficacy of pre-mating supplementation with mono propylene glycol on reproductive performance of cows in commercial dairy herds. Proceedings of the New Zealand Society of Animal Production; 2004; 64: 53-57. 